\title{
Employability and Competence Skills of Graduating Students in a Private Higher Educational Institution in Taguig City, Metro Manila, Philippines
}

\author{
Marlon B. Raquel ${ }^{1 *}$, Henry B. Raquel ${ }^{2}$, Melven B. Raquel ${ }^{3}$, Beryl T. Carloto ${ }^{4}$ \\ ${ }^{1,2,3,4}$ College of Business Administration and Accountancy, The Fisher Valley College, Taguig City, Philippines \\ * Corresponding author: raquel.marlon@yahoo.com
}

\begin{abstract}
Policy makers in the Philippines are focusing on the gaps between the knowledge and skills provided by higher educational institutions and the job opportunities available in the labor market. Graduates are often faced with challenges in looking for jobs right after graduation, thus, schools play a crucial role in ensuring that students are equipped with knowledge and competency skills.

This study examines the level of employability and competence skills of the 309 graduating students taking up different degree programs of The Fisher Valley College located in Taguig City, Metro Manila. About $17.8 \%$ of the respondents are currently working and $21.7 \%$ wanted to work in the service sector. More than half of the total respondents wanted to work in the government. Most of the respondents will look for a job immediately after graduation. Communication skills are the most important of skills in order for them to get hired in their first job applications. The most important factor identified when selecting an organization or company for work is when it provides ample opportunities for them for career advancement. Among workrelated values, respondents considered love for God and perseverance and hard work as the most important.

Five components of employability skills were identified: (1) problem-solving and analytic; (2) learning; (3) personal organization and time management; (4) creativity, innovation, and change; and (5) personal strengths. Overall, students assessed that these skills are very important in employment. However, they reported lower competency levels on these skills particularly on solving problems, identifying essential components of the problem, sorting out the relevant data to solve the problem, and contributing to group problem solving.

It is very important for all sectors, i.e., schools, government, and industry, to prepare the students acquire the necessary skills and provide them with opportunities as they enter the labor market.
\end{abstract}

ARTICLE INFORMATION

$\begin{array}{ll}\text { Received: } & \text { 10-Aug-2019 } \\ \text { Revised: } & \text { 15-Aug-2019 } \\ \text { Accepted: } & \text { 29-Aug-2019 }\end{array}$

DOI: $10.31580 /$ jmi.v6i3.967

\section{INTRODUCTION}

Entering the labor market is one of the major life-defining events in a graduate's professional life after graduation. However, there still exists a gap between the level of employability skills of graduates and their competency skills acquired during their stay in college and often, work requirements do not meet with these skills (Ranasinghe, 1992; Lindsay, 2002).

Higher educational institutions should make sure that they know the status of their graduates. Tracer studies are in fact encouraged to determine the employment status of the graduates. One way of measuring the effectiveness of the service delivery of universities and colleges is by looking at the employability of their graduates (Orence \& Laguador, 2013; Loquias, 2015).

Policy makers in the Philippines are focusing on the gaps between the knowledge and skills provided by higher educational institutions and the job opportunities available in the labor market. Graduates are often faced with challenges in looking for jobs right after graduation, thus, schools play a crucial role in ensuring that students are equipped with knowledge and competency skills.

Thus, this study examines the levels of employability and competence skills of graduating students in The Fisher Valley College, a private higher educational institution located in Taguig
City, Metro Manila. The study aims to answer the following research questions:

1. What is the profile of the graduating students in terms of selected socio-demographic characteristics?

2. What are the work-related values which are considered important in gaining employment?

3. What are the levels of importance and competence of employability skills of graduating students in terms of problem-solving and analytic, learning, personal organization and time management, creativity, innovation, and change, and personal strengths?

\section{LITERATURE REVIEW}

Employability is notoriously complex to define, but for the purposes of this review we have looked at research that uses the term 'employability' and which intersects with one of the key concepts which are contained with the Higher Education Academy's (HEA's) Framework for embedding employability. The framework was used both to provide keywords for the literature review, and to help in structuring our report. Higher education providers are under considerable pressure from policymakers, students and employers to ensure that graduates emerge from higher education ready for the 
labour market. The imminent implementation of the Teaching Excellence Framework (TEF) looks set to increase this pressure (HEA, 2016).

It is also possible to argue that a focus on employability is a moral duty for higher education providers. Students invest their time and money in accessing higher education with the expectation that it will offer them access to greater life chances than they would have obtained if they had not attended HE. For the most part, this expectation is fulfilled with graduates generally doing better in the labor market than non-graduates. However, it is not simply holding a degree that results in these outcomes (although there is an important signaling effect), rather it is critical that higher education develops students in ways that support them to be successful in the future.

Academic interest in employability appears to be growing. Academics are wrestling with the nature of employability, its political implications, the ways in which it is delivered and the relative efficacy of each of them. Academics approach these questions from a range of political, theoretical, methodological and professional perspectives.

\section{METHODOLOGY/MATERIALS}

\section{Research Design and Sample Size}

This study uses a descriptive, quantitative research design. It is primarily descriptive because it describes the characteristics of the respondents.

A total of 320 graduating students for second semester, academic year 2018-2019 were given survey questionnaires but only 309 questionnaires were completely answered. Eleven questionnaires were considered spoiled due to many items left unanswered, thus, the response rate is $95.24 \%$.

There were 109 graduating students from the College of Business Administration and Accountancy who are taking up Bachelor of Science in Accountancy and Bachelor of Science in Business Administration major in Management. Eighty three (83) graduating students are from the College of Hospitality Management taking up Bachelor of Science in Hotel and Restaurant Management. From the College of Computer Studies, 75 graduating students participated in the study who are taking up Bachelor of Science in Information Technology and Bachelor of Science in Computer Science. There were 42 respondents who are taking up Bachelor of Elementary Education and Bachelor of Secondary Education under the College of Education.

\section{Instrumentation and Data Analysis}

Survey questionnaire is the main instrument used in this study. Questionnaire items included in the instrument were selected sociodemographic characteristics of the respondents, employment-related data, competencies acquired at school, work-related values, and levels of importance and competence of employability skills of the respondents.

Questions are designed on a 5-point Likert scale rating anchored on ' 1 ' with range of means 1.00-1.79 for not important/not competent, ' 2 ' with range of means 1.80-2.59 for less important/less competent, ' 3 ' with range of means 2.60-3.39 for moderately important/moderately competent, '4' with means 3.40-4.19 for important/competent, and ' 5 ' with means $4.20-5.00$ for very important/very competent.

Frequencies, percentage distributions, weighted means, verbal interpretations, and ranks were employed to analyze the results of the study.

\section{RESULTS AND FINDINGS}

Table 1. Profile of the Respondents

\begin{tabular}{|c|c|c|}
\hline Variables & Frequency & Percentage \\
\hline \multicolumn{3}{|l|}{ Age Groups } \\
\hline $18-19$ & 114 & 36.9 \\
\hline $20-21$ & 114 & 36.9 \\
\hline 22 and above & 81 & 26.2 \\
\hline \multicolumn{3}{|l|}{ Sex } \\
\hline Male & 162 & 52.4 \\
\hline Female & 147 & 47.6 \\
\hline \multicolumn{3}{|l|}{ Civil Status } \\
\hline Single & 292 & 94.5 \\
\hline Married & 17 & 5.5 \\
\hline \multicolumn{3}{|l|}{ Religion } \\
\hline Roman Catholic & 259 & 80.9 \\
\hline Non-Roman Catholic & 59 & 19.1 \\
\hline \multicolumn{3}{|l|}{ College } \\
\hline CBAA & 109 & 35.3 \\
\hline $\mathrm{CCS}$ & 75 & 24.3 \\
\hline $\mathrm{COE}$ & 42 & 13.6 \\
\hline $\mathrm{COHM}$ & 83 & 26.9 \\
\hline \multicolumn{3}{|l|}{ Monthly Family Income } \\
\hline $\mathrm{P} 10,000$ and below & 141 & 45.6 \\
\hline P10,001-P20,000 & 53 & 17.2 \\
\hline P20,001-P30,000 & 63 & 20.4 \\
\hline P30,001-P40,000 & 4 & 1.3 \\
\hline P40,001-P50,000 & 26 & 8.4 \\
\hline $\mathrm{P} 50,001-\mathrm{P} 60,000$ & 8 & 2.6 \\
\hline P60,001-P70,000 & 10 & 3.2 \\
\hline Over P70,000 & 4 & 1.3 \\
\hline \multicolumn{3}{|l|}{ Employment Status } \\
\hline Currently Working & 54 & 19.4 \\
\hline Not Working & 249 & 80.6 \\
\hline Total & 309 & 100.0 \\
\hline
\end{tabular}

Table 1 shows the frequency and percentage distributions of respondents by selected socio-demographic characteristics. Results show that 18 to 21 years old respondents comprise $73.8 \%$ of the total respondents while $26.2 \%$ of the students are 22 years old and above. There are more males than females $(52.4 \%$ vs. $47.6 \%)$. An overwhelming majority of the respondents are single (94.5\%) while $5.5 \%$ of the respondents are married. In this survey, "single" refers to those who have never married and "married" denotes those who had a partner (including common-law marriage). Of the 309 respondents, 250 (80.9\%) students are Roman Catholics while only 59 (19.1\%) are in other religions.

One hundred nine (109) students are from the College of Business Administration and Accountancy, 83 students are from the College of Hospitality Management, 75 students are taking up programs under the College of Computer Studies while the remaining 42 students are taking up programs under the College of Education. There are 141 respondents or $45.6 \%$ of the total number of respondents who have a monthly family income of P10,000.00 or less. About $17.2 \%$ of the respondents have monthly income between P10,001 to P20,000.00 while $20.4 \%$ has income between P20,001 to P30,000. The remaining percentage has income above $\mathrm{P} 30,000.00$. As to employment status, 249 respondents or $80.6 \%$ are not working while $17.8 \%$ of the total respondents are currently working.

Table 2. What occupation category do you want to work after graduation?

\begin{tabular}{lcc}
\hline $\begin{array}{l}\text { What occupation category do you want to work } \\
\text { after graduation? }\end{array}$ & $\begin{array}{l}\text { Freq } \\
\text { uency }\end{array}$ & $\begin{array}{l}\text { Percent } \\
\text { age }\end{array}$ \\
\hline Services & 67 & 21.7 \\
Technical & 30 & 9.7 \\
Operations & 6 & 1.9 \\
Business Process Outsourcing & 13 & 4.2
\end{tabular}




\begin{tabular}{lcc}
\hline Banking and Finance & 43 & 13.9 \\
Human Resources & 35 & 11.3 \\
Academe/Teaching & 51 & 16.5 \\
Telecommunications & 2 & 0.6 \\
Trade/Industry & 5 & 1.6 \\
Others & 57 & 18.4 \\
\hline Total & $\mathbf{3 0 9}$ & $\mathbf{1 0 0 . 0}$ \\
\hline
\end{tabular}

Table 2 indicates the respondents' choice of occupation category after graduation. The service sector is the top choice of the respondents $(21.7 \%)$, followed by academe or teaching $(16.5 \%)$, banking and finance (13.9\%), and human resources (11.3\%). Others wanted to work in the technical, business process outsourcing, operations, and trade or industry. The remaining $18.4 \%$ of the respondents choose to work in other fields.

From the table above, many students wanted to work in occupations which are outlined within the business administration and accountancy programs. This can be attributed to the fact that there is a high demand in the local and global workplace and diverse business environments that produces intangible goods, more precisely services for business graduates. Countries with economies focused on the service sector are considered more advanced than other markets. This perception is paralleled by Uhlig, et al (2017) when they affirmed that employees with business administration and accountancy degrees have higher earnings, job security and job satisfaction.

Table 3. What type of company/organization do you want to work? What type of company/organization

\begin{tabular}{lcc} 
do you want to work? & Frequency & Percentage \\
\hline Private & 124 & 40.1 \\
Government & 185 & 59.9 \\
\hline Total & $\mathbf{3 0 9}$ & $\mathbf{1 0 0 . 0}$ \\
\hline
\end{tabular}

The person's response to employability concern is determined by the type of organization he is engaged in, hence, variable was examined by the researchers and data relating to the type of organization is depicted in Table 3. Surprisingly, majority of the respondents $(59.9 \%)$ wanted to work in the government sector as contrast to $40.1 \%$ who wanted to get an employment in private companies. Many graduating students are enthusiastic to take their career paths in the government due to the benefits and job security. These factors make government positions beneficial.

Table 4 . Is there any member of your family who attended in this school?

\begin{tabular}{lll}
\hline $\begin{array}{l}\text { Is there any member of your family who } \\
\text { attended in this school? }\end{array}$ & $\begin{array}{l}\text { Freque } \\
\text { ncy }\end{array}$ & $\begin{array}{l}\text { Percent } \\
\text { age }\end{array}$ \\
\hline Yes & 139 & 45.0 \\
No & 170 & 55.0 \\
\hline Total & $\mathbf{3 0 9}$ & $\mathbf{1 0 0 . 0}$ \\
\hline
\end{tabular}

Students were asked whether or not there are family members who attended in the same institution. While more than half $(55.0 \%)$ of the respondents stated in the negative, the remaining $45 \%$ who said that there are family members who also attended in the same institution is considered a high percentage.

Table 5. What is your plan after graduation?

\begin{tabular}{lcc}
\hline What is your plan after graduation? & $\begin{array}{l}\text { Frequen } \\
\text { cy }\end{array}$ & $\begin{array}{l}\text { Percenta } \\
\text { ge }\end{array}$ \\
\hline Look for a job immediately & 249 & 80.6 \\
Currently working, continue with my present & 16 & 5.2 \\
employment & & \\
Start my own business & 5 & 1.6 \\
Join family business & 7 & 2.3 \\
Pursue further studies & 10 & 3.2 \\
Migrate & 11 & 3.6 \\
Rest & 1 & 0.3
\end{tabular}

\begin{tabular}{ccc}
\hline Do not have any idea yet & 10 & 3.2 \\
\hline Total & $\mathbf{3 0 9}$ & $\mathbf{1 0 0 . 0}$ \\
\hline
\end{tabular}

Respondents were also asked about their plans after graduation as shown in Table 5. Around 249 or $80.6 \%$ of the respondents were decided to look for a job immediately while $5.2 \%$ of the graduating students will continue working in their present employment. Eleven (11) students stated that they will migrate or go abroad while 10 students will pursue further studies, i., will be taking master's degrees. Seven (7) students will join family businesses and five (5) students will start their own businesses. There are 10 students who do not have any idea yet what to do while one student stated that he will not do anything but rest.

The result confirms that majority of respondents were willing to look for a job immediately or after graduation in order to utilize their level of education. Both male and female respondents regardless of course programs convinced that college education is an important investment that helps people build their skills and prepare for highskilled jobs. Historically, those who have made this investment have received a substantial economic benefit that lasts over their lifetime (Abel et al., 2014).

However, there have been reports of newly minted college graduates who are unsuccessful at finding jobs suited to their level of education and those who do find work are often confined to low-wage positions (Vedder et al., 2013). Moreover, some factors may hinder in finding a job is due to a mismatch between the aspirations of graduates and employment opportunities available and the influence of career choice decisions for an individual's career (Nyamwange, 2016).

Table 6. How much is your expected gross monthly salary as new graduate?

\begin{tabular}{ccc}
\hline What is your plan after graduation? & Frequency & Percentage \\
\hline P10,000 and below & 249 & 80.6 \\
P10,001-P12,000 & 16 & 5.2 \\
P12,001-P15,000 & & \\
P15,001-P17,000 & 5 & 1.6 \\
P17,001-P20,000 & 7 & 2.3 \\
P20,001-P22,000 & 10 & 3.2 \\
P22,000-P25,000 & 11 & 3.6 \\
P25,001-P27,000 & 1 & 0.3 \\
Over P27,000 & 10 & 3.2 \\
\hline Total & $\mathbf{3 0 9}$ & $\mathbf{1 0 0 . 0}$ \\
\hline
\end{tabular}

Table 6 shows the expected gross monthly salary of respondents as new graduates. it is clear that the most number of respondents belongs to the salary range of 10,000 and below that accounts to $80.6 \%, 16$ or $5.2 \%$ from $10,001-12,000,11$ or $3.6 \%$ from $20,001-$ $22,000,10$ or $3.2 \%$ from $17,001-20,000$ and $25,001-27,000$, respectively. Seven respondents or $2.3 \%$ from $15,001-17,000$ salary range, 5 or $1.6 \%$ from $12,001-15,000,1$ or $0.3 \%$ from $22,000-25,000$ and the monthly salary of over 27,000 is the lowest point or insignificant.

The analysis validates findings in previous research that newly graduates would accept jobs with low salaries since they do not have professional experiences yet and they can change jobs within a year (Barea and Vasudeva, 2015). Salary is not a constraint for the right people. Recent graduates expressed that they would desire to work at a firm with a satisfied social atmosphere and accept a lower salary, rather than receive high salaries with less entertainment.

Table 7. Which of the following competencies is the most important to you in order to be hired in a company?

\begin{tabular}{lcccc}
$\begin{array}{l}\text { Which of the following competencies is the } \\
\text { most important to you in order to be hired } \\
\text { in a company? }\end{array}$ & $\begin{array}{c}\text { Freq } \\
\text { uency }\end{array}$ & $\begin{array}{c}\text { Perce } \\
\text { ntage }\end{array}$ & Rank \\
\hline Communication Skills & 171 & 55.3 & 1 \\
Critical Thinking Skills & 27 & 8.7 & 3 \\
Entrepreneurial Skills & 60 & 19.4 & 2
\end{tabular}




\begin{tabular}{lccc}
\hline Human Relations Skills & 17 & 5.5 & 6 \\
Information Technology Skills & 16 & 5.2 & 5 \\
Problem-solving Skills & 18 & 5.8 & 4 \\
\hline Total & $\mathbf{3 0 9}$ & $\mathbf{1 0 0 . 0}$ & \\
\hline
\end{tabular}

Table 8. Which of the following factors is the most important to you when selecting an organization or company for work?

Which of the following factors is the most important to you when selecting an organization or company for work?

Provides ample opportunities for career advancement Has opening for my preferred field of interest

Presence of friends or relatives in the company

Near my residence

Others

Total

\begin{tabular}{cc}
$\begin{array}{c}\text { Freq } \\
\text { uency }\end{array}$ & $\begin{array}{c}\text { Perce } \\
\text { ntage }\end{array}$ \\
\hline 189 & 61.2 \\
48 & 15.5 \\
8 & 2.6 \\
59 & 19.1 \\
5 & 1.6 \\
\hline $\mathbf{3 0 9}$ & $\mathbf{1 0 0 . 0}$ \\
\hline
\end{tabular}

Table 8 shows the list of factors which are considered the most important for the respondents when selecting an organization or company for work. Out of the 309 respondents, 189 (61.2\%) indicated that they will choose a company that provides ample opportunities for career advancement while about $19.1 \%$ will consider a company if it is near their places of residence. About $15.5 \%$ of the respondents will choose an organization that provides job opening for their preferred field of interest while $2.6 \%$ or eight respondents indicated that the presence of friends or relatives in the company is the most important factor. Meanwhile, five (5) respondents mentioned other reasons.

It is interesting to note that when growth opportunities are abundant and environment is conducive, individuals work with considerably more vigor. This is possible to have an influence on the responses of the respondents. Research has shown unequivocally that greater career development leads to increased productivity and commitment. $\mathrm{Li}$ et al. (2016) examined the impact of career development on employee commitment among part-time faculty in Hong Kong University. They found out that career development have a significantly positive influence on employee commitment. Kraimer et al. (2011) asserted that perceived growth opportunities offered have been linked to higher job performance and lower turnover rate.

In recent decades, career development has seen a shift in the way it is approached. Traditionally, it was up to an organization to ensure that its employees had the skills to meet the company's long-term goals. This shift has changed the way that organizations handle career development. Employer invests in their employees via career development in order to improve organizations' competitive ultimately. They undertook that career development should be nuanced and tailored to individual needs and stages of career. Lee and Bruvold (2003) claimed that equipping employees with competencies, new knowledge and skills means investment in career development that can enable them to accept new challenges outside or within the organization.

Table 9. Means, Standard Deviations, Verbal Interpretations, and Ranks of Work-related Values

\begin{tabular}{lcccc}
\hline Work-related Values & Means & $\begin{array}{c}\text { Std. } \\
\text { Dev. }\end{array}$ & $\begin{array}{c}\text { Verbal } \\
\text { Interpretations }\end{array}$ & $\begin{array}{c}\text { Ran } \\
\text { ks }\end{array}$ \\
\hline Courage & 4.485 & .796 & MI & 5 \\
Creativity and & 4.418 & .816 & MI & 9 \\
innovativeness & 4.246 & .956 & MI & 15 \\
Efficiency & 4.401 & .894 & MI & 10 \\
Fairness and Justice & 4.492 & .763 & MI & 4.5 \\
Honesty and love for truth & 4.492 & .917 & MI & 4.5 \\
Leadership & 4.440 & .777 & MI & 7 \\
Love for Co-workers and & & & & 1 \\
others & 4.563 & .926 & VI & 1 \\
Love for God & 4.340 & .969 & MI & 13 \\
Nationalism & 4.311 & 1.054 & MI & 14 \\
Obedience to superior & 4.528 & .877 & VI & 2 \\
Perseverance and hard & & & &
\end{tabular}

work

$\begin{array}{lllll}\text { Professional Integrity } & 4.495 & .907 & \text { MI } & 3\end{array}$

$\begin{array}{lllll}\text { Punctuality } & 4.437 & .908 & \text { MI } & 8\end{array}$

$\begin{array}{lllll}\text { Supportiveness } & 4.359 & .949 & \text { MI } & 11\end{array}$

\begin{tabular}{lllll} 
Tolerance & 4.346 & .977 & MI & 12 \\
\hline
\end{tabular}

\begin{tabular}{lllll} 
Unity & 4.453 & 1.058 & MI & 6 \\
\hline
\end{tabular}

Composite Mean Score $4.425 \quad$ MI

Table 9 exhibits work related values which are very much considered in finding employment among graduating students. Love for God and perseverance and hard work are very important with weighted means of 4.563 and 4.528 , respectively. The rest of the work-related values are considered moderately important. Interestingly, obedience to superior and efficiency got the lowest mean scores of 4.311 and 4.246 , respectively.

Refozar, Vasquez and Luistro (2017) found that hard work ranked second among work-related values which contribute to meeting the demands of employment among business and computer management graduates in a Philippine university. The consistency of the results is not surprising given the fact that Filipinos are hardworking individuals. They wanted to help their families who have supported them in their studies.

Based on the present study, love for God continues as the dominant work-related values or very important to the job placement of the graduates. In this today's complex, fast-faced, demanding and volatile business environment this is most appealing. Reave (2005) detailed that spiritual values (including Love for God) animates transcendent quality of work. When individuals possess such values are more likely to increased productivity, lowered rates of turnover, greater sustainability, and able to promote positive work relationships. It is interesting to note that an individual regardless of caste or occupation embraces their sense of spirituality able to handle the conflicts, paradoxes and ambiguities (Silver, 2013).

Therefore, aligning an employee's values specifically love of God coupled with graduate's perseverance and hard work will surely foster loyalty and a bond between employer and employee (Buenviaje, et al., 2015).

Table 10. Levels of Importance and Competence of Employability Skills of the Graduating Students

\begin{tabular}{|c|c|c|c|c|c|c|c|c|}
\hline \multirow{2}{*}{$\begin{array}{l}\text { Problem-solving and } \\
\text { Analytic }\end{array}$} & \multicolumn{4}{|c|}{ Level of Importance } & \multicolumn{4}{|c|}{ Level of Competence } \\
\hline & $\tilde{x}$ & SD & $\begin{array}{l}\text { V } \\
\text { I }\end{array}$ & $\mathbf{R}$ & $\tilde{x}$ & SD & V & $\mathbf{R}$ \\
\hline 1. Solving problems & 4.372 & .923 & $\begin{array}{l}\mathrm{V} \\
\mathrm{I}\end{array}$ & 1 & 4.220 & .832 & $\begin{array}{l}\mathrm{V} \\
\mathrm{C}\end{array}$ & 5 \\
\hline \begin{tabular}{ll|}
2. & Identifying \\
problems
\end{tabular} & 4.311 & .901 & $\begin{array}{l}\mathrm{V} \\
\mathrm{I}\end{array}$ & $\begin{array}{l}3 . \\
5\end{array}$ & 4.356 & .881 & $\begin{array}{l}\mathrm{V} \\
\mathrm{C}\end{array}$ & 2 \\
\hline $\begin{array}{ll}3 . & \text { Prioritizing } \\
\text { problems }\end{array}$ & 4.307 & .915 & $\begin{array}{l}\mathrm{V} \\
\mathrm{I} \\
\end{array}$ & 4 & 4.367 & .902 & $\begin{array}{l}\mathrm{V} \\
\mathrm{C} \\
\end{array}$ & 1 \\
\hline $\begin{array}{l}\text { 4. Identifying } \\
\text { essential components } \\
\text { of the problem }\end{array}$ & 4.311 & .943 & $\begin{array}{l}\mathrm{V} \\
\mathrm{I}\end{array}$ & $\begin{array}{l}3 . \\
5\end{array}$ & 4.223 & .999 & $\begin{array}{l}\mathrm{V} \\
\mathrm{C}\end{array}$ & $\begin{array}{l}4 . \\
5\end{array}$ \\
\hline $\begin{array}{l}\text { 5. Sorting out the } \\
\text { relevant data to solve } \\
\text { the problem }\end{array}$ & 4.288 & .821 & $\begin{array}{l}\mathrm{V} \\
\mathrm{I}\end{array}$ & 5 & 4.223 & .949 & $\begin{array}{l}\text { V } \\
\mathrm{C}\end{array}$ & $\begin{array}{l}4 . \\
5\end{array}$ \\
\hline $\begin{array}{l}\text { 6. Contributing to } \\
\text { group problem solving }\end{array}$ & 4.366 & .879 & $\begin{array}{l}\mathrm{V} \\
\mathrm{I} \\
\end{array}$ & 2 & 4.288 & .921 & $\begin{array}{l}\text { V } \\
\mathrm{C}\end{array}$ & 3 \\
\hline $\begin{array}{l}\text { Composite Mean } \\
\text { Score }\end{array}$ & 4.326 & & $V I$ & & 4.280 & & $\begin{array}{l}V \\
C\end{array}$ & \\
\hline
\end{tabular}

\begin{tabular}{|l|l|l|l|l|l|l|l|l|}
\hline \multirow{2}{*}{ Learning } & \multicolumn{9}{|c|}{ Level of Importance } & \multicolumn{3}{|c|}{ Level of Competence } \\
\cline { 2 - 9 } & $\tilde{x}$ & SD & V & $\mathbf{R}$ & $\tilde{x}$ & SD & V & R \\
\hline $\begin{array}{l}\text { 1. Keeping up-to-date } \\
\text { on developments in } \\
\text { the field }\end{array}$ & 4.502 & .771 & V & 3 & 4.372 & .879 & V & 3 \\
\hline 2. Gaining new & 4.557 & .744 & V & 1 & 4.482 & .820 & V & 2 \\
\hline
\end{tabular}




\begin{tabular}{|l|l|l|l|l|l|l|l|l|}
\hline $\begin{array}{l}\text { knowledge in areas } \\
\text { outside the immediate } \\
\text { job }\end{array}$ & & & $\mathrm{I}$ & & & & $\mathrm{C}$ & \\
\hline $\begin{array}{l}\text { 3. Gaining new } \\
\text { knowledge from } \\
\text { everyday experiences }\end{array}$ & 4.521 & .816 & $\mathrm{~V}$ & 2 & 4.521 & .828 & $\mathrm{~V}$ & 1 \\
\hline $\begin{array}{l}\text { Composite Mean } \\
\text { Score }\end{array}$ & 4.526 & & VI & & 4.459 & & V & \\
\hline
\end{tabular}

\begin{tabular}{|c|c|c|c|c|c|c|c|c|}
\hline \multirow{2}{*}{$\begin{array}{l}\text { Personal } \\
\text { Organization and } \\
\text { Time Management }\end{array}$} & \multicolumn{4}{|c|}{ Level of Importance } & \multicolumn{4}{|c|}{ Level of Competence } \\
\hline & $\tilde{x}$ & SD & $\begin{array}{l}\text { V } \\
\text { I }\end{array}$ & $\mathbf{R}$ & $\tilde{x}$ & SD & V & $\mathbf{R}$ \\
\hline $\begin{array}{l}\text { 1. Allocating time } \\
\text { efficiently }\end{array}$ & 4.447 & .883 & $\begin{array}{l}\mathrm{V} \\
\mathrm{I}\end{array}$ & 2 & 4.372 & .901 & $\begin{array}{l}\mathrm{V} \\
\mathrm{C}\end{array}$ & 2 \\
\hline 2. Setting priorities & 4.499 & .812 & $\begin{array}{l}\text { V } \\
\mathrm{I}\end{array}$ & 1 & 4.346 & .922 & $\begin{array}{l}\mathrm{V} \\
\mathrm{C}\end{array}$ & 3 \\
\hline $\begin{array}{l}\text { 3. Managing / } \\
\text { overseeing several } \\
\text { tasks at once }\end{array}$ & 4.275 & .956 & $\begin{array}{l}\mathrm{V} \\
\mathrm{I}\end{array}$ & 4 & 4.220 & .992 & $\begin{array}{l}\mathrm{V} \\
\mathrm{C}\end{array}$ & 4 \\
\hline 4. Meeting deadlines & 4.324 & .970 & $\begin{array}{l}\mathrm{V} \\
\mathrm{I} \\
\end{array}$ & 3 & 4.395 & .893 & $\begin{array}{l}\mathrm{V} \\
\mathrm{C} \\
\end{array}$ & 1 \\
\hline $\begin{array}{l}\text { Composite Mean } \\
\text { Score }\end{array}$ & 4.386 & & $V I$ & & 4.333 & & $\begin{array}{l}V \\
C\end{array}$ & \\
\hline
\end{tabular}

\begin{tabular}{|c|c|c|c|c|c|c|c|c|}
\hline \multirow{2}{*}{$\begin{array}{l}\text { Creativity, } \\
\text { Innovation and } \\
\text { Change }\end{array}$} & \multicolumn{4}{|c|}{ Level of Importance } & \multicolumn{4}{|c|}{ Level of Competence } \\
\hline & $\tilde{x}$ & SD & $\begin{array}{l}\text { V } \\
\text { I }\end{array}$ & $\mathbf{R}$ & $\tilde{x}$ & SD & VI & $\mathbf{R}$ \\
\hline $\begin{array}{l}\text { 1. Adapting to } \\
\text { situations of change }\end{array}$ & 4.366 & .950 & $\begin{array}{l}\mathrm{V} \\
\mathrm{I} \\
\end{array}$ & 2 & 4.346 & .901 & $\begin{array}{l}\mathrm{V} \\
\mathrm{C}\end{array}$ & 4 \\
\hline $\begin{array}{l}\text { 2. Keeping up-to-date } \\
\text { with external realities } \\
\text { related to your } \\
\text { company's success }\end{array}$ & 4.375 & .909 & $\begin{array}{l}\text { V } \\
\mathrm{I}\end{array}$ & 1 & 4.401 & .834 & $\begin{array}{l}\mathrm{V} \\
\mathrm{C}\end{array}$ & 2 \\
\hline $\begin{array}{l}\text { 3. Re-conceptualizing } \\
\text { your role in response } \\
\text { to changing corporate } \\
\text { realities }\end{array}$ & 4.324 & .900 & $\begin{array}{l}\mathrm{V} \\
\mathrm{I}\end{array}$ & 4 & 4.392 & .844 & $\begin{array}{l}\mathrm{V} \\
\mathrm{C}\end{array}$ & 3 \\
\hline $\begin{array}{l}\text { 4. Initiating change to } \\
\text { enhance productivity }\end{array}$ & 4.363 & .911 & $\begin{array}{l}\text { V } \\
\mathrm{I}\end{array}$ & 3 & 4.414 & .885 & $\begin{array}{l}\text { V } \\
\mathrm{C}\end{array}$ & 1 \\
\hline $\begin{array}{l}\text { 5. Providing novel } \\
\text { solutions to problems }\end{array}$ & 4.262 & .999 & $\begin{array}{l}\mathrm{V} \\
\mathrm{I} \\
\end{array}$ & 5 & 4.249 & 1.006 & $\begin{array}{l}\mathrm{V} \\
\mathrm{C} \\
\end{array}$ & 5 \\
\hline $\begin{array}{l}\text { Composite Mean } \\
\text { Score }\end{array}$ & 4.338 & & $\begin{array}{l}V \\
I\end{array}$ & & 4.361 & & $\begin{array}{l}\mathrm{V} \\
\mathrm{C}\end{array}$ & \\
\hline
\end{tabular}

\begin{tabular}{|l|l|l|l|l|l|l|l|l|}
\hline \multirow{2}{*}{ Personal Strengths } & \multicolumn{9}{|c|}{ Level of Importance } & \multicolumn{3}{|c|}{ Level of Competence } \\
\cline { 2 - 9 } & $\tilde{x}$ & SD & $\begin{array}{l}\text { I } \\
\text { I }\end{array}$ & $\mathbf{R}$ & $\tilde{x}$ & SD & VI & R \\
\hline $\begin{array}{l}\text { 1. Functioning well in } \\
\text { stressful situations }\end{array}$ & 4.453 & .898 & V & 2 & 4.314 & .988 & V & 5 \\
\hline $\begin{array}{l}\text { 2. Functioning at an } \\
\text { optimal level of } \\
\text { performance }\end{array}$ & 4.353 & 1.007 & V & 6 & 4.275 & .993 & V & 6 \\
\hline $\begin{array}{l}\text { 3. Responding } \\
\text { positively to } \\
\text { constructive criticism }\end{array}$ & 4.379 & .982 & V & 5 & 4.356 & .910 & V & 4 \\
\hline $\begin{array}{l}\text { 4. Maintaining a } \\
\text { positive attitude }\end{array}$ & 4.469 & .913 & V & 1 & 4.385 & .962 & V & 2 \\
\hline $\begin{array}{l}\text { 5. Maintaining a high } \\
\text { energy level }\end{array}$ & 4.440 & .943 & V & 3 & 4.369 & 1.054 & V & 3 \\
\hline $\begin{array}{l}\text { 6. Ability to work } \\
\text { independently }\end{array}$ & 4.427 & .939 & V & 4 & 4.398 & .919 & V & 1 \\
\hline $\begin{array}{l}\text { Composite Mean } \\
\text { Score }\end{array}$ & 4.425 & & VI & & 4.350 & & V & \\
\hline
\end{tabular}

Table 10 shows the levels of importance and competence of employability skills of graduating students. Learning skills are considered very important and at the same time, respondents reported very competent in these areas. It is very important for them to gain new knowledge in areas outside of their immediate job and from everyday experiences and keeping up-to-date on the developments in the field.

Among the five skills, problem-solving and analytical skills ranked fifth in terms of importance and competence as perceived by the respondents. While verbal interpretations suggest that these are very important and respondents claimed that they are very competent in identifying and solving problems, this is worthy of taking into scrutiny.

One striking result in this study is that the levels of competence of all employability skills are lower than the levels of importance except for creativity, innovation, and change. This means that while students believe that these skills are very important, they reported lower levels of competence. This can be attributed to the fact that they still lack the necessary experiences which are very important in getting employed.

Overall, graduating students consider all employability skills as very important with a composite mean score of 4.40. They also believe that they are very competent in these areas with a composite mean score of 4.356 .

\section{CONCLUSION}

One in every five students is currently working while studying. The concept of work-study balance has been an ongoing struggles for many young Filipinos who do not want to stop their college studies. Universities, private companies, and government agencies, therefore, have to implement programs that would help these working students cope up this daunting task before them. Most of the graduating students wanted to work in the government. This is quite interesting because in the past decades, Filipinos did not want to join government because of low salaries. The trend was reversed in the past few years due to increases of salaries among government employees which encourages many young professionals to join the government. These future professionals also want to engage in the service sector. Services sector posted the highest share of GDP in the fourth quarter of 2018 which is $56.2 \%$ (DTI, 2018).

Communication skills are considered the most important of all skills, thus, schools should strengthened the English curriculum, particularly oral and writing skills, so that students would be ready to face job interviews. In addition, since Filipinos are considered religious, schools have to reinforce teaching religious and moral values which are important in the workplaces. Work values should be integrated in all aspects of classroom teaching and trainings and seminars.

While students reported a relatively high importance and competence in all employability skills, it is noteworthy that they reported lowest competency levels in terms of problem-solving and analytical skills. These sets of skills are important in examining situations to identify the strengths and weaknesses so that they would be able to make recommendations how to solve problems in their respective companies where they will be employed.

\section{REFERENCES}

Bagaoisan, A. J. (2015). Why Filipinos are among world's most religious. In Global Attitudes Survey Pew Research Center. Retrieved at https://news.abs-cbn.com/focus/01/07/16/why-filipinos-are-amongworlds-most-religious

Barea, D. and Vasudeva, P. (2015). Will Today's Graduates Want to Work For You? London: Accenture.

Baring, R. \& Cacho, R. (2015). Contemporary engagements and challenges for Catholic religious education in Southeast Asia. In Global Perspectives on Catholic Religious Education in Schools. Edited by Michael Buchanan and Adrian Gellel. Basel: Springer Publishing, pp. 143-53.

Buenviaje, M.G., Galicano, V.M., Añonuevo, F. \& Martinez, M. (2015). Employability of Business and Computer Management Graduates of 
one Higher Education Institution in the Philippines, Asia Pacific Journal of Academic Research in Business Administration, 3(5): 63-71

Higher Education Academy (2016). Framework for Embedding employability in higher education. Retrieved from https://www.heacademy.ac.uk/system/files/downloads/embeddingemployability-in-he.pdf

Jones, C. G. (2011). Written and Computer-Mediated Accounting Communication Skills An Employer Perspective. Business Communication Quarterly, 74(3), 247-271.

Kraimer, M. L., Seibert, S. E., Wayne, S. J., \& Liden, R. C. (2011) Antecedents and outcomes of organizational

support for development: The critical role of career opportunities. Journal of Applied Psychology, 96,

485-500

Kraimer, M. L., Seibert, S. E., Wayne, S. J., \& Liden, R. C. (2011) Antecedents and outcomes of organizational

support for development: The critical role of career opportunities. Journal of 485-500

Kraimer, M. L., Seibert, S. E., Wayne, S. J., \& Liden, R. C. (2011) Antecedents and outcomes of organizational support for development: The critical role of career opportunities. Journal of Applied Psychology, 96, 485-500.

Lee, C. H., \& Bruvold, N. T. (2003). Creating value for employees: investment in employee development. The International Journal of Human Resource Management, 14(6), 981-1000.

Lindsay, C. (2002). Long-term unemployment and the "employability gap": Priorities for renewing Britain's New Deal. Journal of European Industrial Training, 26(9), 411-419.

Li, I. W., Mahuteau, S., Dockery, A., M., Junankar, P. N. \& Mavromaras, K. (2016). Labour market outcomes of Australian university graduates from equity groups. Perth, WA: National Centre for Student Equity in Higher Education (NCSEHE) at Curtin University. https://www.ncsehe.edu.au/wp-content/uploads/2016/03/LabourMarket-Outcomes-ofAustralian-University-Graduates-from-EquityGroups.pdf

Loquias, R. (2015). Employability of the Bachelor of Science in Electronics Engineering Graduates of Camarines Sur Polytechnic Colleges. Asia Pacific Journal of Multidisciplinary Research, 3(4), 33-40.

Nyamwange, J. (2016). Influence of Student's Interest on Career Choice among First Year University Students in Public and Private Universities in Kisii County, Kenya. Journal of Education and Practice, 7(4), 96-102.

Orence, A. \& Laguador, J.M. (2013). Employability of Maritime Graduates of Lyceum of the Philippines University from 2007-2011, International Journal of Research in Social Science, 3(3): 142-157.

Philippine National Accounts, 2015-2018 (Q4). Retrieved from https://www.dti.gov.ph/resources/statistics/gross-domestic-product-gdp

Ranasinghe, S.W. (1992). Human resource development in Sri Lanka: Present trends and future Perspectives. In Salleh, S. and Gurung, S.B. (Eds.), Human Resource Development in South Asia. Asian and Pacific Development Centre, Malaysia.

Refozar, R.F., Velasquez, J.E. \& Luistro, E.J. (2017). Employability of BS Business and Computer Management Graduates from 2013 to 2015 in one Academic Institution in the Philippines, Asia Pacific Journal of Academic Research in Business Administration, 3(3): 1-9

Reave, L. (2005). Spiritual values and practices related to leadership effectiveness. The Leadership Quarterly, 16(5), 655-687.

Silver, C. (2012). Coping with the consequences of 'too many lawyers': Securing the place of international graduate law students. International Journal of the Legal Profession, 19(2-3), 227-245.

Uhlig, R., Mehta, K., Silverstone, S., and Mossavar-Rahmani, F., (2015). The Value of Business Education: A Case Study of Business Administration Graduates of a Large University, Journal of Business and Behavioral Sciences, Vol. 7, Issue 1, p. 89-106, Spring

Vedder, R., Denhart, C., \& Robe, J. (2013). Why are recent college graduates underemployed? University enrollments and labor-market realities. Washington, D.C.: Center for College Affordability and Productivity. 